\title{
Governance and the Split of Options between Executive and Nonexecutive Employees
}

\author{
WAYNE LANDSMAN* \\ MARK LANG* \\ SHU YeH**
}

\begin{abstract}
We examine the determinants and consequences of the split of options between executive and nonexecutive employees. We find that the lower the proportion of options granted to executives is, the stronger firm governance is. For the sample as a whole, the relation between options and both operating income and valuation is weaker for executive options than for options to lower-level employees. Splitting the sample between weak and strong governance firms, for the weak (strong) governance firms, the relation between executive options and firm performance and valuation is weaker (stronger) relative to nonexecutive options. Results are robust to controls for the endogeneity of optiongranting choice. Taken as a whole, our results suggest that firms with relatively weak governance tend to give a larger proportion of options to executives and appear to receive relatively less benefit from those options.
\end{abstract}

Keywords: employee stock options, executive stock options, broad-based options, governance

*Kenan-Flagler Business School, University of North Carolina

**College of Management, National Taiwan University

We are grateful to Jack Ciesielski of R.G. Associates, Inc. for providing employee stock option data used in this study, to the Center for Finance and Accounting Research at UNC-Chapel Hill and the Republic of China National Science Council (Project no. NSC 95-2416-H-002-027) for funding support, and to Allison Evans, seminar participants at the 2006 Journal of Accounting, Auditing \& Finance Conference, particularly the discussant, Venkatesh Nagar, and an anonymous reviewer for comments. 


\section{Introduction}

A growing body of literature examines the consequences of options for valuation and performance. Because of the nature of the data, most researchers consider either executive options from proxy statements or total options from financial statement footnotes. There are many reasons, however, to believe that executive options have different costs and benefits than broad-based plans. Our goal in this paper is to consider explicitly determinants of the decision of how to split options between executive and nonexecutive employees, and the effect of that decision on the relative valuation and performance implications of options.

Existing literature has investigated links between option compensation, and both valuation and future profitability. For example, Bell, Landsman, Miller, and Yeh (2002) find that, for a sample of profitable software companies, the market appears to value outstanding options as assets, suggesting that outstanding options enhance expected future cash flows. Similarly, Aboody, Barth, and Kasznik (2004) consider a sample of small to medium firms and provide evidence that the market values options as an expense, especially once future earnings growth is controlled, suggesting that options represent an asset that is used up over the life of the options. Their focus is on total options outstanding and they do not differentiate between executive and broad-based options. Similarly, Hanlon, Rajgopal, and Shevlin (2003) focus on executive options and find that higher levels of options tend to be associated with future profitability, suggesting that options have positive incentive properties.

It seems fairly clear that the effect of options on firm performance and valuation might depend on the level of employees to whom they are granted. Executive options, for example, are more likely to have significant incentive effects, because executives have more control over factors that affect share price. As a consequence, options granted to executives have the potential to provide greater benefits to the firm. Conversely, if executives have significant influence over compensation packages, it is possible that option grants may be excessive, potentially reducing or eliminating these benefits.

Bebchuk and Fried (2004) argue that compensation schemes are primarily a result of managerial power rather than optimal contracting and provide evidence that executives with greater power receive more pay. ${ }^{1}$ They suggest that, as a consequence, executives may earn excessive compensation, especially when governance is relatively weak. ${ }^{2}$ Consistent with that assertion, recent cases such as those involving Tyco and the New York Stock Exchange (NYSE) suggest a link between relatively weak governance oversight and excessive compensation. This argument is particularly relevant for options because typically they are not

1. See also Core, Guay, and Thomas (2005) for counterarguments.

2. Consistent with that argument, Core, Holthausen, and Larcker (1999) examine the relation between governance, CEO compensation, and firm performance for a sample of 205 firms during 1982-84 and provide evidence that CEOs of firms with weaker governance, and hence greater agency problems, extract greater compensation and such firms have worse future performance. 
expensed and, hence, it may be easier to argue that they have little cost. If so, it is possible that options granted to executives may have reduced incentive effects and valuation implications. This reasoning underlies, at least in part, some of the recent calls for option expensing.

Beyond the direct implications of excess compensation, options may have troubling incentive effects, especially if coupled with weak oversight. For example, executives with excess option compensation may have increased incentives to manipulate earnings or take other actions to artificially inflate share price (Bergstresser \& Philippon [2006]; Erickson, Hanlon, \& Maydew [2006]) or to increase risk (Rajgopal \& Shevlin [2002]). As a consequence, high levels of executive option compensation coupled with relatively weak governance may not increase value sufficiently to justify their cost and may even, in the extreme, reduce shareholder value. ${ }^{3}$

Lower-level stock options are less likely to have some of the problems of executive options, but they raise their own set of issues. It has been argued, for example, that broad-based option plans are not optimal because of the risk/ reward trade-off for lower-level employees (Hall \& Murphy [2003]). To the extent that lower-level employees have limited ability to influence share price and are risk averse, it is possible that options are less efficient than traditional forms of compensation. Potentially exacerbating that issue is the possibility that, if lower-level employees are relatively more risk averse, options will be a more expensive form of compensation (Meulbroek [2001]; Hall \& Murphy [2002]). Conversely, some have argued that broad-based option plans can perform important retention and sorting functions (Ittner, Lambert, \& Larcker [2003]; Oyer \& Schaefer [2005]) and tie compensation to changes in employees' reservation wages (Oyer [2004]).

Compared with executive options, it is more difficult to argue why firms would grant broad-based options if they were not optimal. Even in the case of lower-level employees, however, option granting may reflect the fact that options have not traditionally been expensed under Generally Accepted Accounting Principles (GAAPs). In particular, studies including Hall and Murphy (2003) have argued that many choices with respect to options appear to be driven by accounting treatment. ${ }^{4}$ Employers may be more willing to grant options, even if they are not optimal, because this form of compensation enables them to avoid expense recognition.

The notion that the implications of options may differ by level in the company is reflected in decisions by legislators and regulators. For example, proxy

3. That raises the question of why firms would provide compensation that was not optimal from a shareholder perspective. One possibility is that governance problems may result in decisions that, viewed in isolation, are not optimal from a shareholder perspective, but that reflect a more general decision about the balance of power in the organization (Gompers, Ishii, \& Metrick [2003]).

4. Consistent with the notion that compensation design is affected by accounting treatment, Carter and Lynch (2003) provide evidence that firms changed option terms around changes in the accounting treatment of option repricing. 
statements require disclosure of option holdings as part of executive compensation, although not requiring similar disclosure for employees deeper in the organization, apparently reflecting a belief that the incentive effects of options are likely different for top executives than for lower-level employees. Similarly, the House of Representatives overwhelmingly passed the Stock Option Accounting Reform Act, which would limit option expensing to executives in the firm, arguing that options do not constitute an expense when awarded to lower-level employees. The underlying notion appears to be that executive options are likely to be excessive and should be discouraged, while options to lower-level employees should be encouraged. Although it is difficult to see a strong conceptual rationale for a difference in the accounting treatment of options for executives relative to lower-level employees, even if the costs or incentives differ, it is clear that many view the costs and incentive effects of options as differing across levels of the firm.

Our analysis is based on an examination of the profitability and valuation implications of options, splitting between higher- and lower-level employees. An advantage of comparing the two types of options is that many of the incentives for issuing options are (at least partially) naturally controlled. For example, if firms choose options because they are not expensed for financial reporting, it would not necessarily affect the mix of executive versus lower-level options because both sets are accounted for analogously. Both sets of options are typically treated similarly for tax purposes, so differences in tax incentives should not affect the mix. Also, if options are favored by firms with cash constraints, the incentives should be similar for both types of options. Of course, that raises issues of why otherwise similar firms would choose a different option mix. Because of the potential endogeneity, we include estimation approaches that consider the potential simultaneity of option mix choice.

We begin by examining determinants of the split of option grants between executives and lower-level employees. ${ }^{5}$ We have two primary interests here. First, if we understand determinants of option grants, we are in a better position to address why options distribution differs across firms. Of particular interest is the relation between the proportion of options granted to executives and governance, because one of the concerns with executive option grants is the effect of governance. This setting is particularly interesting because the comparison is effectively within firm, allowing differences in firmwide factors, such as capital needs and accounting considerations, to be naturally controlled. We find, among other things, a significant relation between governance, as measured by the "Governance

5. As discussed below, because of the nature of publicly available data, we are limited to splitting options between the top five executives and other employees in the firm. For convenience, we refer to the top five executives as "executives" and the remaining employees receiving options as "nonexecutives," and refer to plans as "broad based" when a substantial proportion of options are granted to employees below the top five. Our assumption is that firms that grant a larger proportion of options below the top five executives distribute options deeper into the organization. We cannot, however, explicitly track the actual employees who receive options below the top five executives. 
Index" from Gompers, Ishii, and Metrick (2003), and the extent to which option grants are concentrated in the executive suite, which suggests that executives receive a greater proportion of options when governance is relatively weak.

Second, we examine the relation between executive and broad-based options, and operating income and equity market value. We examine operating income and market value because both measures have difficult design issues and consistent evidence across the two provides greater confidence in the results. Furthermore, operating income captures the effect on realized near-term performance while market value captures the market's assessment of the likely effect on future performance. As noted earlier, findings in Hanlon, Rajgopal, and Shevlin (2003, hereafter HRS) suggest a positive relation between executive options and future operating income. Our interest is in the relative size of the coefficient estimates across the two groups because we recognize that omitted correlated variables and noise can influence the coefficient levels.

We conduct our analysis both with Ordinary Least Squares (OLS) and with controls for endogeneity using a two-stage-least-squares estimation approach. In particular, our concern is that factors, including profitability and market value, might affect the choice of how deep in the organization to grant options. We address this concern by using the original specification for the determinants of option split to obtain instruments for executive and nonexecutive options, which are then used to estimate the operating income and market valuation regressions.

Our results suggest that, in general, the coefficient on executive options is smaller than for lower-level options, particularly after controlling for endogeneity. We conduct a similar analysis for market value following Bell, Landsman, Miller, and Yeh (2002, hereafter BLMY), which finds that options carry a positive coefficient in valuation. Consistent with the results for operating income, we find that, on average, the coefficient for executive options is smaller than for options granted deeper into the organization. Again, results are especially strong after including controls for endogeneity.

On the surface, it may seem surprising that the effect of options appears to be smaller for executives than for lower-level employees because, from a riskincentive perspective, it seems likely that executives have more control over firm performance and may be less risk averse. As noted earlier, however, one potential explanation is the effect of governance. If option grants to executives are excessive with relatively weak oversight or if options create pathological incentives (e.g., to manage earnings or increase risk) in the face of weak governance, the value of options in firms with weak governance may be weaker. To investigate this possibility, we examine the relative consequences of options for earnings and valuation by splitting the sample based on governance as measured by the Governance Index. Our results suggest that the relation between options and performance is a function of governance in the sense that executive options have the strongest relation to income and valuation in the presence of strong governance. In particular, in the absence of strong governance, executive options have little or negative consequences for valuation and future profitability. 
Taken as a whole, our results make several potential contributions. First, they suggest the importance of differentiating between executive options and options to lower-level employees. Papers in the literature often do not differentiate between executive options and lower-level options. ${ }^{6}$ However, there are a variety of reasons to expect option costs and benefits to differ based on employee levels in the company. Furthermore, our results highlight the importance of controls for endogeneity. Although controls for endogeneity do not fundamentally change our primary conclusions, they do affect the point estimates and strength of our conclusions.

Second, we provide exploratory evidence on the net benefits of options at varying levels in the organization. Admittedly, it is extremely difficult to draw strong inferences about benefits of various compensation schemes based on evidence such as that in this paper. In the spirit of HRS (2003) and BLMY (2002), our point is that the level in the organization to which options are granted may be important to understanding the implications of options.

Third, the findings complement research such as Gompers, Ishii, and Metrick (2003) on potential reasons for a link between governance and performance. In particular, the findings in Gompers, Ishii, and Metrick (2003) suggest that weak governance is associated with poor firm performance (although Core, Guay, \& Rusticus [2006] question that conclusion). Consistent with Core, Holthausen, and Larcker (1999), our results suggest a link between weak governance, executive compensation and firm performance.

Fourth, our findings suggest that disclosure of options by level in the company may be useful in understanding the implications of options for investors. Currently, footnote option disclosure is aggregated across all options outstanding. However, to the extent that options at different levels in the organization have different valuation implications, disaggregation across levels may be important.

The remainder of the paper is organized as follows. Section 2 presents estimating equations. Section 3 describes the sample and data. Section 4 presents our findings and Section 5 discusses robustness tests. Section 6 summarizes and concludes the study.

6. An exception is a study by Ittner, Lambert, and Larcker (2003), which examines the structure and performance consequences of equity grants for a proprietary data set of new economy firms with relatively detailed compensation data. They provide evidence that option-granting behavior is significantly different relative to old economy firms. New economy firms indicate that employee retention and attraction is a primary goal of option issuance, and their empirical results suggest that employee retention (but not attraction) is an important determinant of grants to new employees (but not existing employees) across all levels of the organization. Furthermore, they provide some evidence that lower-than-expected option grants are associated with lower future stock returns and return on assets two years in the future, but find little evidence that firms with higher-than-expected option grants have lower subsequent performance. Another exception is Callaghan, Stanford, and Subramaniam (2006), which shows that stock option grants to executives and lower-level employees are value creating for the firm. Although these findings appear to contradict ours, the tests in Callaghan, Stanford, and Subramaniam (2006) are based on separate estimations for executive and nonexecutive employees, which contrasts with our tests that include both employee grants simultaneously. 


\section{Empirical Approach}

\subsection{Determinants of the Split between Executive and Nonexecutive Option Grants}

Existing literature is not clear as to which variables to include to explain the proportion of options granted to executives, because most prior research focuses on either the overall level of executive grants or of firmwide grants, but not their relative proportions. The estimating equation we use is based on that used in Core and Guay (2001) to estimate the determinants of nonexecutive incentive grants, eq. (2) in their study. Our estimating equation differs from theirs because we have a different focus. In particular, Core and Guay (2001) investigate whether cash or financing constraints affect nonexecutive grants, while we are interested in the determinants of the relative proportion or "split" of option fair values granted to executives and nonexecutives, which should be less affected by the firm's cash position. Because we later use the split regression fitted value to control for endogeneity in the operating income and market valuation regressions, we also include lagged operating income in the estimating equation. Finally, we include the Governance Index as a measure of corporate governance, GOV. The Governance Index is a combination of twenty-four shareholder protection characteristics. It seems particularly appropriate in this context because it captures the extent to which managers are shielded from shareholder oversight by, for example, permitting firms to delay hostile bidders; limiting shareholder voting rights; insuring officers and directors against termination and liability; and other takeover defenses. A firm with a high governance score is one for which the management is relatively shielded from shareholder oversight and, therefore, for which management is more likely to have the ability to behave dictatorially.

The option split model is given by eq. (1):

$$
\begin{aligned}
\operatorname{SPLIT}_{i t}= & \alpha_{0}+\alpha_{1} \ln (E M P L)_{i t}+\alpha_{2} \ln (S A L E S)_{i t}+\alpha_{3} R D_{i t}+\alpha_{4} B M_{i t} \\
& +\alpha_{5} G O V_{i t}+\alpha_{6} O I_{i t-1}+\varepsilon_{i t}
\end{aligned}
$$

where

$S P L I T=E S O /[E S O+X S O]$

$E S O=$ Fair value of nonexecutive option grants, measured as fair value of total employee option grants, per Statement of Financial Accounting Standards (SFAS) No. 123 disclosure, less XSO

$X S O=$ Fair value of top five executive option grants, per ExecuComp

$\ln (E M P L)=$ Logarithm transformation of the number of employees

$\ln (S A L E S)=$ Logarithm transformation of annual sales (Compustat item 12)

$R D=$ Research and development (R\&D) expenses (Compustat item 46), deflated by sales. Following HRS, a value of 0 is assigned when it is missing from Compustat 
$B M=$ Book value of equity at year-end (Compustat item 60) divided by equity market value at year-end (Compustat item 25 multiplied by item 199)

$G O V=$ Gomper, Ishii, and Metrick's (2003) Governance Index. Higher values indicate lower shareholder rights ${ }^{7}$

$O I=$ Operating Income before R\&D expenses after Sales, General and Administration (SG\&A) (Compustat item 13 plus item 46), deflated by sales

We expect a positive coefficient for $R D$ and a negative coefficient for $B M$ because firms with more research and development and resulting intangible assets are likely to have more technical employees who have greater influence on share price. We make no predictions on the sign of the $\ln (E M P L)$ and $\ln (S A L E S)$ coefficients, but we include those variables to control for firm differences relating to size as measured by sales and the number of employees. We predict the coefficient on $G O V$ will be negative to the extent that firms with better corporate governance (lower values of $G O V$ ) are less likely to overcompensate their executives relative to nonexecutive employees. We do not have a prediction for $O I$ because it is not clear how profitability will affect the option split between executive and nonexecutive employees. We estimate eq. (1) pooling available firm-year observations, using year and industry fixed effects.

\subsection{Implications of Executive and Nonexecutive Option Grants}

\subsubsection{Operating Income Equations}

We base our operating income equations on those in HRS (2003), which predicts and finds evidence that granting options to executives results in higher future operating income. ${ }^{8}$ In contrast to HRS, our estimating equations include both ESO and $X S O$ to determine the marginal effects of each on future profitability. ${ }^{9}$

$$
O I_{i t}=\alpha_{0}+\alpha_{1} T a_{i t-1}+\alpha_{2} \sum_{s=t-2}^{t} X S O_{i s}+\alpha_{3} \sum_{s=t-2}^{t} E S O_{i s}+\varepsilon_{i t}
$$

7. The Gomper, Ishii, and Metrick's (2003) Governance Index is constructed from data prepared by the Investor Responsibility Research Center (IRRC). Gomper, Ishii, and Metrick (2003) classified twenty-four governance factors in the IRRC database into five groups (tactics for delaying hostile takeover, voting rights, director/officer protection, other takeover defenses, and state laws), and create their Index by summing twenty-four binary governance factors.

8. An alternate approach to estimating the operating income eq. (2) and the valuation eq. (3) below is to base the analysis on "excess" options from a first-stage regression of options on economic determinants under the assumption that options affect profitability and valuation only when they deviate from optimal levels (Ittner, Lambert, \& Larcker [2003]). We apply our approach to measuring the effect of options for consistency with BLMY (2002) and the primary tests of HRS (2003).

9. In interpreting our results, it is important to note that there is no overlap in options between $X S O$ and ESO (i.e., options included in XSO are not also included in ESO), so the coefficient on XSO is not incremental to the coefficient on ESO. For ease of exposition, we use the same notation for coefficients and error terms in eqs. (1) and (2), as well as eq. (3) below. 
Our specification differs from that in HRS in two ways. First, whereas HRS includes current and lagged values of executive grants for the prior five years, we include only data for executive and nonexecutive grants for the current and prior two years because the employee stock option data disclosed under SFAS No. 123, "Accounting for Stock-Based Compensation" (FASB [1995]) only extend back to 1996 and including five-year lagged data would severely limit our sample. Second, HRS includes separate regressors for each of the current and prior five-year executive grants, permitting each to have its own coefficient, while we sum our executive and nonexecutive grant fair values, effectively constraining each lagged amount to have the same coefficient. This research design choice reflects a trade-off between the cost of unstable coefficients in the yearto-year option grant fair values arising from their high colinearity (see HRS [2003], Table 2) and the cost of imposing the same coefficient on each of the lagged option grant fair values. ${ }^{10}$ Conceptually, one can view $\sum X S O$ and $\sum E S O$ as proxies for the likely value of outstanding options because options are typically held for multiple years before exercise.

We compare the relative implications of options to executive and nonexecutive employees by testing the null $\alpha_{2}=\alpha_{3}$ in eq. (2) using an $F$-test. Following HRS, eq. (2) includes beginning total assets (Compustat item 6) as a control for size differences, and each of the variables in the estimating equations is deflated by sales, SALES (Compustat item 12), corresponding to the year the variable is measured. In particular, each of the lagged XSO and ESO amounts in year $t$ is deflated by SALES in year $t$. As with eq. (1), we estimate eq. (2) pooling available firm-year observations using year and industry fixed effects.

\subsubsection{Valuation Equations}

Our market valuation equation is based on that employed by BLMY (2002), in which equity market value is regressed on residual income, equity book value, option expense per SFAS No. 123, and a book value measure of an intangible asset arising from current and past option grants. Our valuation regressions include equity book value, residual income, $\sum X S O$ and $\sum E S O$ As with the operating income equation, we estimate models that include $\sum X S O$ and $\sum E S O$ to simultaneously determine the marginal relation between $\sum X S O$ and $\sum E S O$ and current equity market value. The equity valuation model is given by eq. (3):

$$
M V E_{i t}=\alpha_{0}+\alpha_{1} B V E_{i t}+\alpha_{2} R I_{i t}+\alpha_{3} \sum_{s=t-2}^{t} X S O_{i s}+\alpha_{4} \sum_{s=t-2}^{t} E S O_{i s}+\varepsilon_{i t}
$$

10. As discussed below, findings are robust to estimating separate coefficients on lagged option grant fair values and basing inferences on XSO and ESO coefficient sums. 
Following prior research (Barth, Beaver, Hand, \& Landsman [1999]; Dechow, Hutton, \& Sloan [1999]; Bell, Landsman, Miller, \& Yeh [2002]), we measure residual income as net income (Compustat item 18) less 12 percent of lagged equity book value.

The current study differs from BLMY in several ways. First, our estimating equations include the fair value of options granted in the current and prior two years, rather than option expense and the intangible asset. In principle, the two approaches are similar in that the sum of the prior year executive and nonexecutive option fair values likely is highly correlated with the intangible asset measure in BLMY. An advantage of the current research design is that no accounting method is imposed when constructing the employee stock option variables. As with the operating income eq. (2), we compare the relative valuation effect of granting options to executive and nonexecutive employees by testing the null $\alpha_{3}=\alpha_{4}$ in eq. (3) using an $F$-test. Second, whereas BLMY are interested in examining the valuation properties of option fair value disclosures within the context of the Ohlson (1995) model, we do not assume that the Ohlson model necessarily holds. Our interest is in whether options are associated with incremental valuation after considering the book value of equity and residual income. We expect that, if outstanding options increase expected cash flows, there should be positive coefficients on $\sum X S O$ and $\sum E S O$, and the relative magnitudes of the two coefficients provide insight on differences in the expected cash flow implications of the two classes of options. As with eqs. (1) and (2), we estimate eq. (3) pooling available firm-year observations using year and industry fixed effects, and deflating all variables by sales.

\subsection{Impact of Corporate Governance on Income and Valuation Equations}

To examine the effect of governance on profitability and valuation, we split our sample using GOV, based on the Governance Index, because the likelihood of excess executive compensation may be greater and potential pathological effects of options more pronounced with worse corporate governance, all other things equal. As a consequence, the relation between executive options and income and valuation may vary based on governance environment. We predict that better corporate governance will be associated with a higher XSO coefficient relative to the ESO coefficient for the operating income and market valuation equations. To test this proposition, we estimate eqs. (2) and (3) separately for subsamples of high- and low-governance firms based on the median value of $G O V$, which is 10 . As with the pooled sample, we then compare the relative valuation effect of granting options to executive and nonexecutive employees separately for high- and low-GOV observations by testing the null $\alpha_{2}=\alpha_{3}$ in eq. (2) and $\alpha_{3}=\alpha_{4}$ in eq. (3) and by testing the relative magnitude of $\alpha_{2}$ and $\alpha_{3}$ between the high- and low-GOV partitions. ${ }^{11}$

11. We test whether the $\sum E S O$ and $\sum X S O$ coefficient magnitudes differ for high- and lowGovernance Index observations by estimating pooled regressions including an indicator variable for high- and low-Governance Index values and interaction variables $G \times \sum E S O$ and $G \times \sum X S O$. 


\subsection{Two-Stage-Least-Squares Estimation}

As noted by Larcker (2003) in his discussion of HRS, that study's operating income regressions likely suffer from endogeneity bias arising from the fact that profitability affects option-granting behavior. This concern may apply equally to valuation regressions. To address this problem, we estimate a two-stage-leastsquares procedure, using predicted values of SPLIT from a version of eq. (1) to construct instruments for $\sum X S O$ and $\sum E S O$, which are then used when estimating eqs. (2) and (3).

The procedure works as follows. ${ }^{12}$ First, we estimate eq. (1), excluding GOV as an explanatory variable. We exclude $G O V$ because we do not want the instruments we construct to reflect the effects of corporate governance, to avoid "throwing away the baby with the bath water" when we test for operating income and valuation coefficient differences based on governance. ${ }^{13}$ Second, we construct "predicted" instruments for $\sum X S O$ and $\sum E S O, X S O P$ and ESOP, based on the following formulas:

$$
\begin{gathered}
E_{S O P}=\sum_{s=t-2}^{t} \operatorname{SPLIT}_{i s} \times\left(E_{\text {SSO }}+X S O_{i s}\right) \\
X S O P_{i, t}=\sum_{s=t-2}^{t}(1-S P L I T) \times\left(E S O_{i s}+X S O_{i s}\right)
\end{gathered}
$$

where $S P L I T_{i t}$ is the fitted value from eq. (1) with $G O V$ omitted from the model. Third, we reestimate eqs. (2) and (3) using XSOP and ESOP in place of $\sum X S O$ and $\sum E S O$. We also reestimate eqs. (2) and (3) for subsamples of high- and low-governance firms as described in Section 2.3 using XSOP and ESOP. XSOP and ESOP have the desired property of being constructed from exogenous variables to ensure that each is uncorrelated with the error term in the operating income and valuation equations. Although this type of simultaneous estimation has the potential advantage of controlling for endogeneity, it implicitly assumes that the instruments and total option grants are exogenously determined. ${ }^{14}$ To the extent that the first-stage SPLIT regression is of low power, this procedure will tend to bias against finding significant coefficients for XSOP and ESOP in the operating income and valuation regressions.

12. Our two-stage-least-squares approach is a variant of the two-stage procedure described in Kmenta (1971), in which predetermined variables in a system of equations are used to construct instruments for the endogenous variables, which in our case are SPLIT, ESO, and XSO.

13. As discussed later, our conclusions are not sensitive to the exclusion of $G O V$ in the estimation.

14. We assume that with respect to the split decision, the determinants of SPLIT in eq. (1) are fixed. In principle, employees, sales, $R \& D$ expenditures, and governance are jointly determined along with the decision of relative option grants to higher- and lower-level employees. Nonetheless, untabulated findings for the operating earnings and valuation equations based on alternative SPLIT instruments result in similar inferences to those based on findings reported in Panel B of Tables 3 through 6. 


\section{Sample and Data}

The sample includes 1,170 firm-year observations drawn from Standard \& Poor's (S\&P) 500 Industrial Index. ${ }^{15}$ The sample period includes fiscal years 1996-2001, but the sample observations are from 1998-2001 because we require three years of option data. We begin with 1996 because that is the first year for which SFAS No. 123 data are available. The potential sample for use in our cross-sectional regression is 2,000 observations. We require firms to have earnings, equity market value, (nonnegative) equity book value, estimates of fair value of employee stock option grants disclosed under SFAS No. 123, fair value of executive stock option grants, and a Governance Index score. Earnings, equity book value and equity market value data are drawn from the Compustat database. The fair value of employee stock option grants per SFAS No. 123 disclosures are from a database provided to us by Jack Ciesielski of R.G. Associates, Inc. We obtain the fair value of executive stock option grants from the ExecuComp database, ${ }^{16}$ and the Governance Index data from Andrew Metrick's Web site (http://finance.wharton.upenn.edu/metrick/data.htm). ${ }^{17}$

To mitigate the effects of outliers, for each variable appearing in the estimating equations, we treat as missing any observations that are in the extreme top and bottom one percentile (Kothari \& Zimmerman [1995]; Collins, Maydew, \& Weiss [1997]; Fama \& French [1998]; Barth, Beaver, Hand, \& Landsman [1999, 2005]). Table 1, Panel A, summarizes how we obtain the final sample of 1,170 firm-year observations used in the operating income and valuation regressions after imposing the various sampling requirements. The largest loss of observations, 766 , results from summing option fair values over three years to obtain the key explanatory variables, $\sum X S O$ and $\sum E S O .^{18}$

Table 1, Panels B and C, present descriptive statistics and Spearman and Pearson correlations for the variables used in the study. Panel B indicates that

15. We focus on the S\&P 500 firms because we were able to obtain machine-readable data on the fair value of employee stock option grants and because they are large and stable firms. Although ExecuСотр provides some data on the number of securities underlying equity grants to executives relative to other employees, the data are frequently missing, and to conduct our empirical analysis, it is important to measure accurately the total fair value of options granted.

16. The ExecuComp database provides stock option grant information for only the top five executives. Thus, it is not possible to distinguish which option grants below the top five executives relate to other executives and which relate to broad-based option plans.

17. Studies using the Governance Index include Bebchuk and Cohen (2005); Bowen, Rajgopal, and Venkatachalam (2004); Ashbaugh, Collins, and LaFond (2006); and Bergstresser, Desai, and Rauh (2006). Several of the studies use the Governance Index to represent a broad index of corporate governance although it is regarded by many as primarily an anti-takeover protection index (Brown \& Caylor [2006]). See Section 5 for a discussion of robustness tests that use alternative governance measures based on subsets of the Governance Index.

18. Note that the split regression include observations for 1996 through 2001, while the operating income and valuation regressions include observations only from 1998 to 2001 because the operating income and valuation regressions require values for $\sum X S O$ and $\sum E S O$, which are constructed using three years of data. This accounts for the loss of the 766 observations that relate to years 1996 and 1997. 
approximately 20 percent of the total fair value of annual option grants are awarded to executives, with the remainder going to lower-level employees. In addition, the sum of average $X S O$ and ESO is of the same order of magnitude as residual income, which averages approximately 2 percent of sales, comparable to levels found in HRS and BLMY. Panel C reports correlations among our variables. In particular, the Pearson correlation between $\sum X S O$ and $\sum E S O$ is 0.68 , indicating that, although firms that grant more options to lower-level employees also tend to grant more options to executives, the variation in lower-level options explains only about 46 percent of the variation in executive options.

\section{TABLE 1}

\section{Descriptive Statistics for a Sample of S\&P 500 Industrial Index Firms, with 1,170 Firm-Year Observations, 1998-2001}

Panel A: Summary statistics of sampling process

Number of

firm years

Firms in S\&P 500 Industrial Index for years 1996-2001

3,000

Less: Firm years with missing SFAS 123 disclosure from J. Ciesielski of

R.G. Associates, Inc. database

Less: Firm years with missing XSO data from ExecuComp

Less: Firm years with missing Governance Index data

Less: Firm years with various financial statement data missing

Less: Top and bottom $1 \%$ trimming for all variables with available data

Less: Firm years lost in summing option fair values over three year period

Total sample firms for years 1998-2001

Panel B: Distributional statistics

\begin{tabular}{lccccc}
\hline \multicolumn{1}{c}{ Variable } & Mean & $\begin{array}{c}\text { 25th } \\
\text { Percentile }\end{array}$ & Median & $\begin{array}{c}\text { 75th } \\
\text { Percentile }\end{array}$ & $\begin{array}{c}\text { Standard } \\
\text { Deviation }\end{array}$ \\
\hline$M V E$ & 2.56 & 0.85 & 1.70 & 3.17 & 2.69 \\
$B V E$ & 0.56 & 0.29 & 0.46 & 0.74 & 0.38 \\
$R I$ & 0.02 & 0.00 & 0.02 & 0.06 & 0.08 \\
OI & 0.25 & 0.15 & 0.22 & 0.33 & 0.14 \\
TA (lagged) & 1.97 & 0.73 & 1.07 & 1.67 & 2.53 \\
RD & 0.03 & 0.00 & 0.00 & 0.04 & 0.06 \\
ESO (in \%) & 1.99 & 0.27 & 0.67 & 1.61 & 4.02 \\
XSO (in \%) & 0.34 & 0.05 & 0.12 & 0.31 & 0.69 \\
$\sum E S O$ (in \%) & 5.23 & 0.84 & 1.94 & 4.33 & 9.86 \\
$\sum X S O$ (in \%) & 0.96 & 0.16 & 0.36 & 0.95 & 1.78 \\
Split & 0.79 & 0.73 & 0.84 & 0.92 & 0.17 \\
GOV & 9.78 & 8.00 & 10.00 & 12.00 & 2.53 \\
$\ln ($ empl) & 3.05 & 2.22 & 3.11 & 3.90 & 1.17 \\
$\ln ($ sales) & 8.61 & 7.81 & 8.59 & 9.36 & 1.07 \\
BM & 0.34 & 0.16 & 0.30 & 0.47 & 0.22 \\
\hline
\end{tabular}




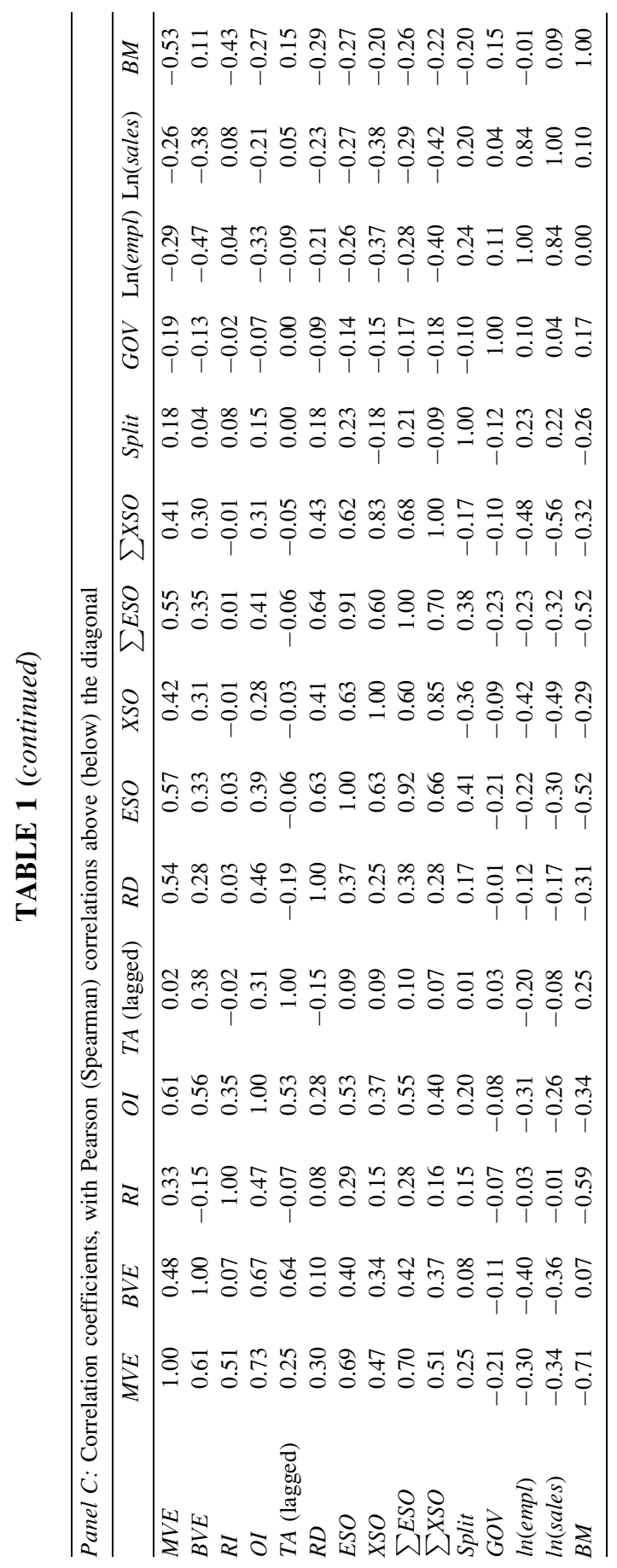


TABLE 1 (continued)

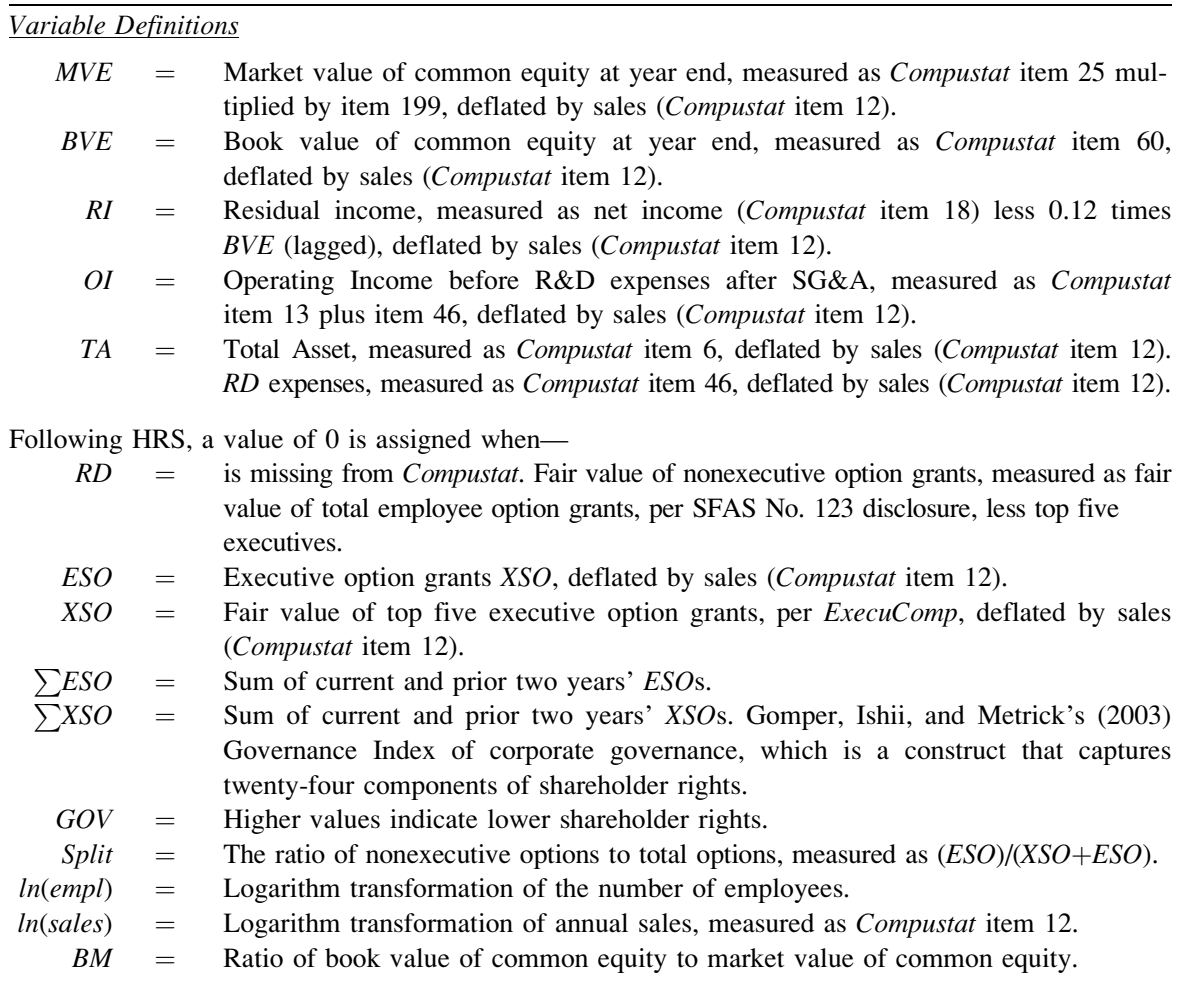

\section{Results}

\subsection{Determinants of Split between Executive and Nonexecutive Option Grants}

Table 2 presents summary statistics from estimating eq. (1), which regresses SPLIT (i.e., the ratio of the fair value of nonexecutive option grants to total option grants, ESO/[ESO $+X S O])$ on our explanatory variables. The first two columns relate to specifications that include the Governance Index variable, $G O V$; the first (second) column excludes (includes) lagged operating income, $O I$. The third and fourth columns present analogous statistics but omit GOV. Predicted values of the dependent variable, SPLIT, from these latter two specifications are used in subsequent tests that address endogeneity of ESO and XSO in the operating income and valuation regression models.

Most regressors in Table 2 have significant coefficients, the exception being $\mathrm{R} \& \mathrm{D}$ expenses in specifications that include lagged operating income. In addition, for those variables for which we have predictions, all coefficients have predicted signs. A larger proportion of options tend to go to lower-level employees for firms 
TABLE 2

\section{Regressions of the Ratio of the Fair Value of Nonexecutive Option Grants to Total Option Grants on Its Determinants*}

\begin{tabular}{|c|c|c|c|c|}
\hline \multicolumn{5}{|c|}{$S P L I T_{i t}=\alpha_{0}+\alpha_{1} \ln (E M P L)_{i t}+\alpha_{2} \ln (S A L E S)_{i t}+\alpha_{3} R D_{i t}+\alpha_{4} B M_{i t}+\alpha_{5} G O V_{i t}+\alpha_{6} O I_{i t-1}+\varepsilon$} \\
\hline & $\begin{array}{c}\text { Dependent } \\
\text { Variable }=\text { Split }\end{array}$ & & & \\
\hline$\overline{\ln (e m p l) i, t}$ & 0.02 & 0.03 & 0.02 & 0.03 \\
\hline$t$-stat. & 3.02 & 3.86 & 2.50 & 3.31 \\
\hline $\ln ($ sales $) i, t$ & 0.02 & 0.02 & 0.02 & 0.02 \\
\hline$t$-stat. & 2.82 & 2.62 & 3.10 & 2.92 \\
\hline$(R D) i, t$ & 0.34 & 0.02 & 0.35 & 0.03 \\
\hline$t$-stat. & 3.27 & 0.16 & 3.30 & 0.24 \\
\hline$(B M) i, t$ & -0.10 & -0.06 & -0.11 & -0.07 \\
\hline$t$-stat. & -4.92 & -2.96 & -5.29 & -3.34 \\
\hline$(G o v) i, t$ & -0.01 & -0.01 & & \\
\hline$t$-stat. & -3.82 & -3.97 & & \\
\hline$(O I) i, t-1$ & & 0.28 & & 0.28 \\
\hline$t$-stat. & & 7.48 & & 7.35 \\
\hline No. of Obs. & 1,936 & 1,916 & 1,936 & 1,916 \\
\hline Adj. $R^{2}$ & 0.116 & 0.140 & 0.110 & 0.133 \\
\hline
\end{tabular}

that are larger, have more employees, spend more on R\&D, and have higher market-to-book ratios. In addition, when lagged operating income, $O_{i t-1}$, is higher, the proportion of options granted to nonexecutive employees is greater. This finding suggests that, holding total options constant, more profitable firms are more likely to extend options deeper into the organization, perhaps to encourage retention and sorting (Oyer \& Schaefer [2005]). Most notable, a higher Governance Index value results in a significantly lower proportion of option fair value granted to nonexecutive employees ( $t$-statistics $=-3.82$ and -3.97$)$, implying that executives in firms with weaker governance receive a relatively larger proportion of options granted.

\subsection{Operating Income and Market Valuation Regressions}

Table 3, Panel A, presents results from estimating the operating income regression, eq. (2), using OLS. The findings in Table 3, Panel A, suggest that option grants predict higher future operating income. The coefficient on $\sum E S O$ is 0.49 , which is significantly positive ( $t$-statistic of 10.21). Interestingly, the coefficient point estimate on $\sum X S O$ is 0.38 , which is smaller than that for $\sum E S O$ and which is insignificant. This result suggests that, after controlling for nonexecutive options, there is no longer a significant relation between future operating income and 
TABLE 3

\section{Regressions of Operating Income with Fair Values of Option Grants Included as Regressors, 1998-2001*}

$\overline{\text { Panel A: Summary statistics from regression of operating income on lagged total asset and fair values }}$ of option grants

\begin{tabular}{|c|c|c|c|c|c|c|c|c|c|}
\hline & & $T A$ & & $\sum X S O$ & & $\sum E S O$ & & $\alpha_{2}=\alpha_{3}$ & \\
\hline Equation & $\begin{array}{c}\text { No. of } \\
\text { Obs. }\end{array}$ & Coefficient & $t$-stat. & Coefficient & $t$-stat. & Coefficient & $t$-stat. & $F$-stat. & Adj. $R^{2}$ \\
\hline (2) & 1,170 & 0.02 & 10.21 & 0.38 & 1.58 & 0.49 & 10.21 & 0.17 & 0.437 \\
\hline
\end{tabular}

Panel B: Summary statistics from regression of operating income on lagged total asset and predicted values of fair values of option grants

$$
O I_{i t}=\alpha_{0}+\alpha_{1} T A_{i t-1}+\alpha_{2} X S O P_{i t}+\alpha_{3} E S O P_{i t}+\varepsilon_{i t}
$$

\begin{tabular}{lccccccrrr}
\hline & \multicolumn{3}{c}{$T A$} & & $\sum X S O$ & \multicolumn{3}{c}{$\sum E S O$} & $\alpha_{2}=\alpha_{3}$ \\
\hline Prediction & $\begin{array}{l}\text { No. of } \\
\text { Obs. }\end{array}$ & & & & & & & \\
\hline Split $1^{* *}$ & 1,170 & 0.02 & 10.27 & -0.16 & -0.38 & 0.62 & 6.51 & 2.38 & 0.438 \\
Split 2** & 1,137 & 0.01 & 9.37 & -1.39 & -4.15 & 0.85 & 11.62 & 31.36 & 0.473 \\
\hline
\end{tabular}

Notes:

*See Table 1 for the definitions of all variables, except for predicted values for $\sum X S O$ and $\sum E S O, X S O P$, and ESOP. XSOP ${ }_{i, t}=\sum_{s=t-2}^{t}\left(1-S_{s} L I T_{i s}\right) \times\left(E S O_{i s}+X S O_{i s}\right) . E S O P=\sum S P L I T \times$ $\left(E S O_{i s}+X S O_{i s}\right)$. SPLIT is the fitted value from option split regression reported in Table 2.

All regressions are estimated with year and industry fixed effects (coefficients and $t$-statistics are not tabulated).

**In the first-stage SPLIT regressions, Split 1 includes $\ln ($ empl), $\ln ($ sales $), R D$, and $B M$, as independent variables, and Split 2 includes lagged $O I$, $\ln ($ empl $), \ln ($ sales $), R D$, and $B M$, as independent variables.

executive option compensation. As noted earlier, an issue with the OLS specification is the possibility that the split between executive and nonexecutive options is endogenous, which results in $\sum E S O$ and $\sum X S O$ not being fixed regressors in the operating income equation. To control for that possibility, we simultaneously estimate the operating income and split regressions. XSOP and ESOP, defined by eqs. (4b) and (4a), are instruments for $\sum X S O$ and $\sum E S O$, which were created using predicted values from the SPLIT regression. The first-stage SPLIT regression results are tabulated in columns three and four of Table 2. To assess the potential importance of endogeneity, we first apply the Hausman $(1978,1983)$ test. Untabulated results suggest significant endogeneity with respect to operating income, but not the market value of equity. For consistency, we report results for both operating income and market value both with and without endogeneity controls. 
Results from the second-stage operating income regressions that control for endogeneity are presented in Table 3, Panel B. We present results from two different instruments, one of which is based on the SPLIT regression that excludes lagged operating income, SPLIT1, and another which includes lagged operating income, SPLIT2. The two-stage-least-squares results are generally consistent with those for OLS. The controls for endogeneity strengthen the positive relation between lower-level options and future operating profit, with the coefficient estimate increasing to 0.62 ( $t$-statistic of 6.51 ) for the specification without operating income in the first stage and to 0.85 ( $t$-statistic of 11.62) for the specification with operating income in the first stage. More interesting, the relation between executive options and future operating profit becomes even weaker after controlling for endogeneity. In both specifications, the coefficient point estimate for executive options is negative after controlling for endogeneity, significantly so for the specification in which the endogeneity control includes operating income. As noted earlier, our primary interest is in the level of the coefficient on executive options relative to nonexecutive options because omitted variables could affect the overall level of our coefficient estimates. After controlling for endogeneity, the coefficient on executive options is below that on nonexecutive options, although only significantly so for the specification with operating income ( $F$-statistic of 31.36).

Results from the market value of equity regression using OLS, reported in Table 4, Panel A, tell a similar story to the operating income results. As with operating income, the relation between nonexecutive options and market value is significantly positive (coefficient estimate of 8.22 and $t$-statistic of 10.46), suggesting that nonexecutive options are valued as assets by the market. As with operating income, however, the coefficient on executive options is insignificant (coefficient estimate of 6.81 and $t$-statistic of 1.78), suggesting that, after controlling for nonexecutive options, there is no remaining significant relation between executive options and market value.

Table 4, Panel B, reports results for the two-stage-least-squares market value regression. As with the results for operating income, the control for endogeneity makes the difference between executive and nonexecutive options even more stark. Including our controls for endogeneity, the relation between nonexecutive options and market value is even stronger, with the coefficient estimate increasing to 13.28 ( $t$-statistic of 8.88) and to 12.79 ( $t$-statistic of 10.31) for the specifications without and with operating income, respectively. As with the operating income results, after controlling for endogeneity, the executive options have a reliably negative effect on valuation ( $t$-statistics of -2.55 and -3.02 , respectively, in the specifications without and with controls for operating income), suggesting that, after controlling for the effects of nonexecutive options and endogeneity, executive options may actually reduce value. More important, the difference in the valuation effect between the executive and nonexecutive options is statistically significant 


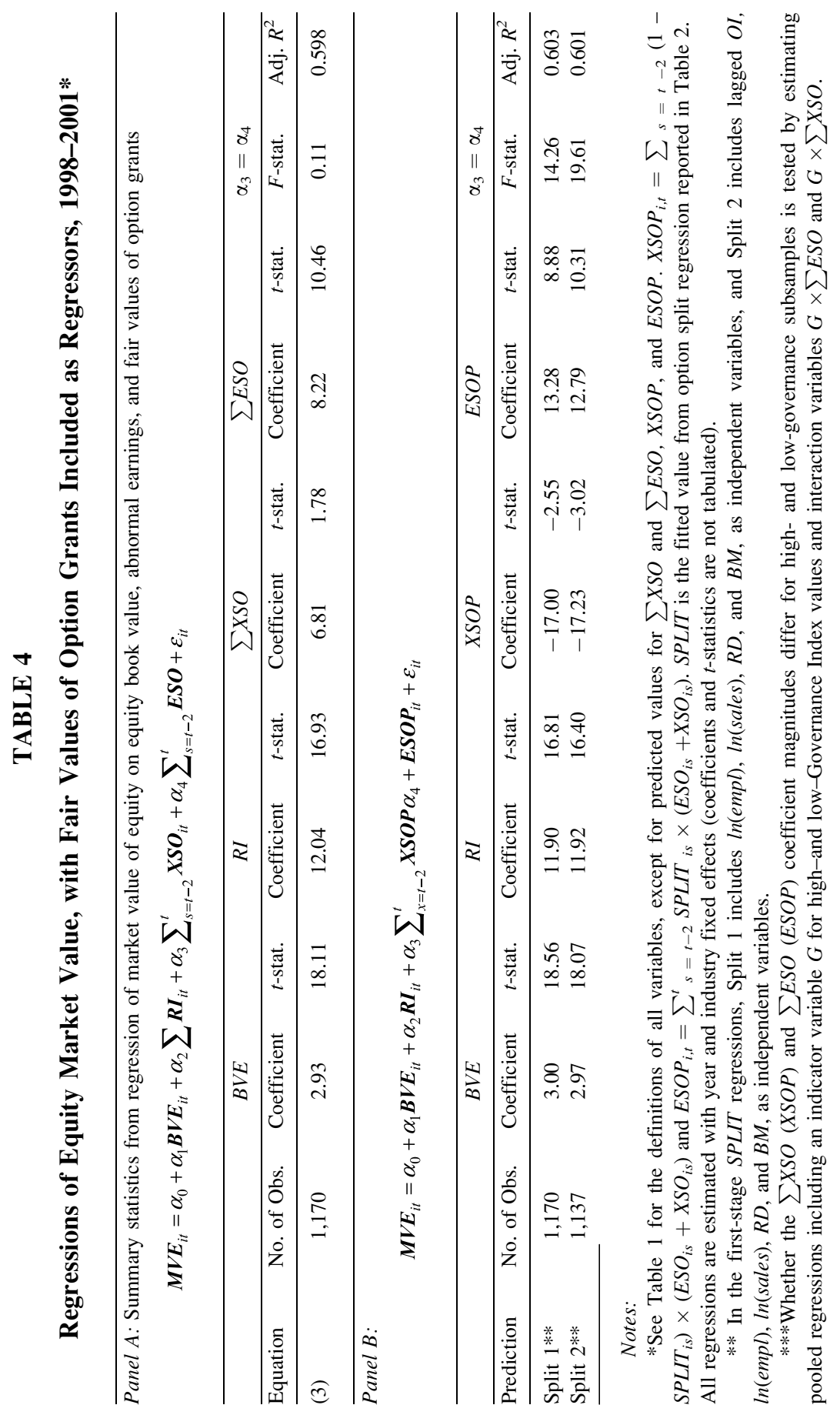


( $F$-statistics of 14.26 and 19.61, respectively, for the specifications without and with controls for operating income). ${ }^{19}$

\subsection{Effect of Governance on Operating Income Prediction and Market Valuation}

Taken as a whole, the preceding results suggest that executive options tend to have less of an effect on future operating income and market value than do nonexecutive options, especially after controlling for endogeneity. That conclusion raises the issue of why that might be the case. The earlier analysis of SPLIT provides a potential explanation. If grants are more likely to be skewed in favor of executives when governance is weak, then it is possible that the weak results for executive options reflect the fact that option grants may be excessive in the face of weak governance and may even, in the extreme, lead to reductions in firm performance and valuation.

To evaluate that possibility, we repeat the analysis by splitting the sample based on $G O V$. Our prediction is that, if option grants and incentives are a function of governance environment, it should be the case that the relations between executive options and operating income and valuation vary based on the governance environment.

Table 5, Panel A, presents summary statistics from estimating the operating income regressions from eq. (2) using OLS, including the fair values of both executive and nonexecutive options. To test for the effects of corporate governance on the $\sum E S O$ and $\sum X S O$ coefficients, Panel A includes two rows that relate to estimations for observations with high and low values for the Governance Index.

Consistent with the pooled results, the coefficient on nonexecutive options is significantly positive for both good and poor governance firms, with coefficient estimates of 0.34 ( $t$-statistic of 5.08) and 0.73 ( $t$-statistic of 9.47), respectively. In terms of the executive options in good governance firms, the relation between executive options and operating income is positive (coefficient estimate of 0.62) and statistically significant ( $t$-statistic of 1.98). For the poor governance firms, however, the coefficient estimate on executive options is negative $(-0.45)$, but not significantly different from 0 ( $t$-statistic of -1.10$)$. More important for our purposes, the coefficient estimate on executive options for poor governance firms is significantly lower than for good governance firms ( $F$-statistic of 6.52). Furthermore, the coefficient on executive options is significantly lower than for nonexecutive options for the poor governance subsample ( $F$-statistic of 6.40$)$, but not for the good governance subsample. In other words, the implications of executive options for future operating income are weaker when governance is poor relative to executive options when governance is strong and relative to nonexecutive options when governance is weak. The fact that the nonexecutive option

19. Untabulated findings from regressions without fixed effects result in similar inferences to those associated with findings reported in Tables 3 and 4. 
coefficient is larger for poor governance firms provides some assurance that the relatively weak results for executive options do not simply reflect the fact that options generally add less value for poor governance firms. Rather, it appears that nonexecutive options for poor governance firms provide at least as much marginal benefit as for strong governance firms. However, the endogeneity of option split could affect our conclusions. Table 5, Panel B, presents results using two-stage-least-squares estimation. As before, controlling for endogeneity tends to strengthen the relation between nonexecutive options and future operating income. In all specifications, the relation between nonexecutive options and future operating performance is positive and significant. As was the case with the pooled regressions, however, including controls for endogeneity weakens the relation between executive options and future profitability even further, resulting in insignificant coefficient estimates for the good governance sample. Moreover, for the poor governance sample, the coefficient on executive options is negative after controlling for endogeneity, significantly so in the specification with controls for operating income ( $t$-statistic of -3.56). Most important for our purposes, the coefficient estimates for executive options are significantly lower than for nonexecutive options for both specifications of the endogeneity controls ( $F$-statistics of 3.95 and 22.33, respectively, for the specifications without and with controls for operating income). Furthermore, the coefficient estimates for executive options for the poor governance firms are significantly below those for the good governance firms for both specifications ( $F$-statistics of 4.59 and 3.96, respectively). As with the OLS specification, the results suggest that governance has a significant effect on the relation between executive options and future earnings with poor governance firms benefiting less from executive options than strong governance firms.

Conclusions are similar for the market valuation results presented in Table 6 . The OLS regression results in Panel A show the coefficient estimates for nonexecutive options are significantly positive for the weak and strong governance firms. As with the operating income results, however, the effect of executive options on valuation differs markedly depending on the governance environment. The coefficient estimates on executive options go from being significantly positive for the good governance firms ( $t$-statistic of 2.57) to being negative and marginally significant ( $t$-statistic of -1.81 ) for the poor governance firms, a reduction that is statistically significant ( $F$-statistic of 9.63). Furthermore, the coefficient estimate on executive options goes from being insignificantly higher than that on nonexecutive options for good governance firms to significantly lower for poor governance firms ( $F$-statistic of 10.57). Again, it appears that the association between executive options and valuation is lower (and may even be negative) when governance is relatively weak.

Table 6, Panel B, presents the two-stage market valuation regression results. As with operating income, controlling for endogeneity generally strengthens our conclusions. As before, the relation between nonexecutive options and firm value is positive and at least as strong for both governance subsamples after including 


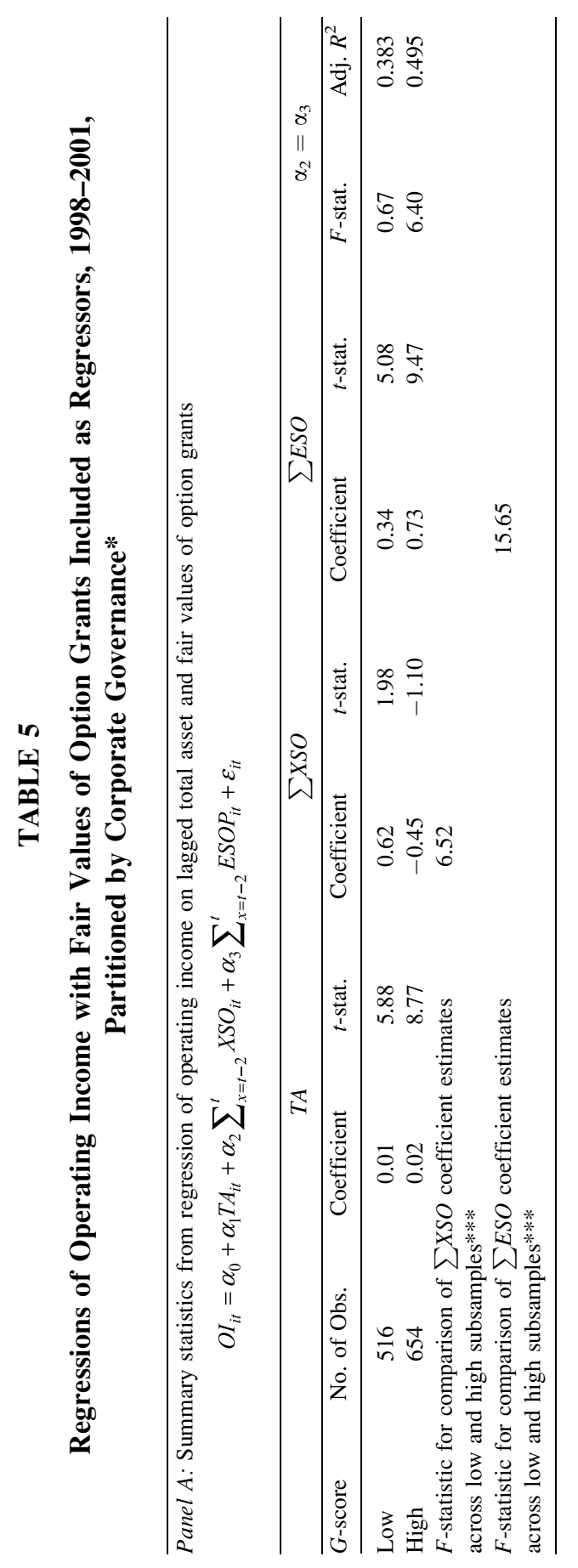




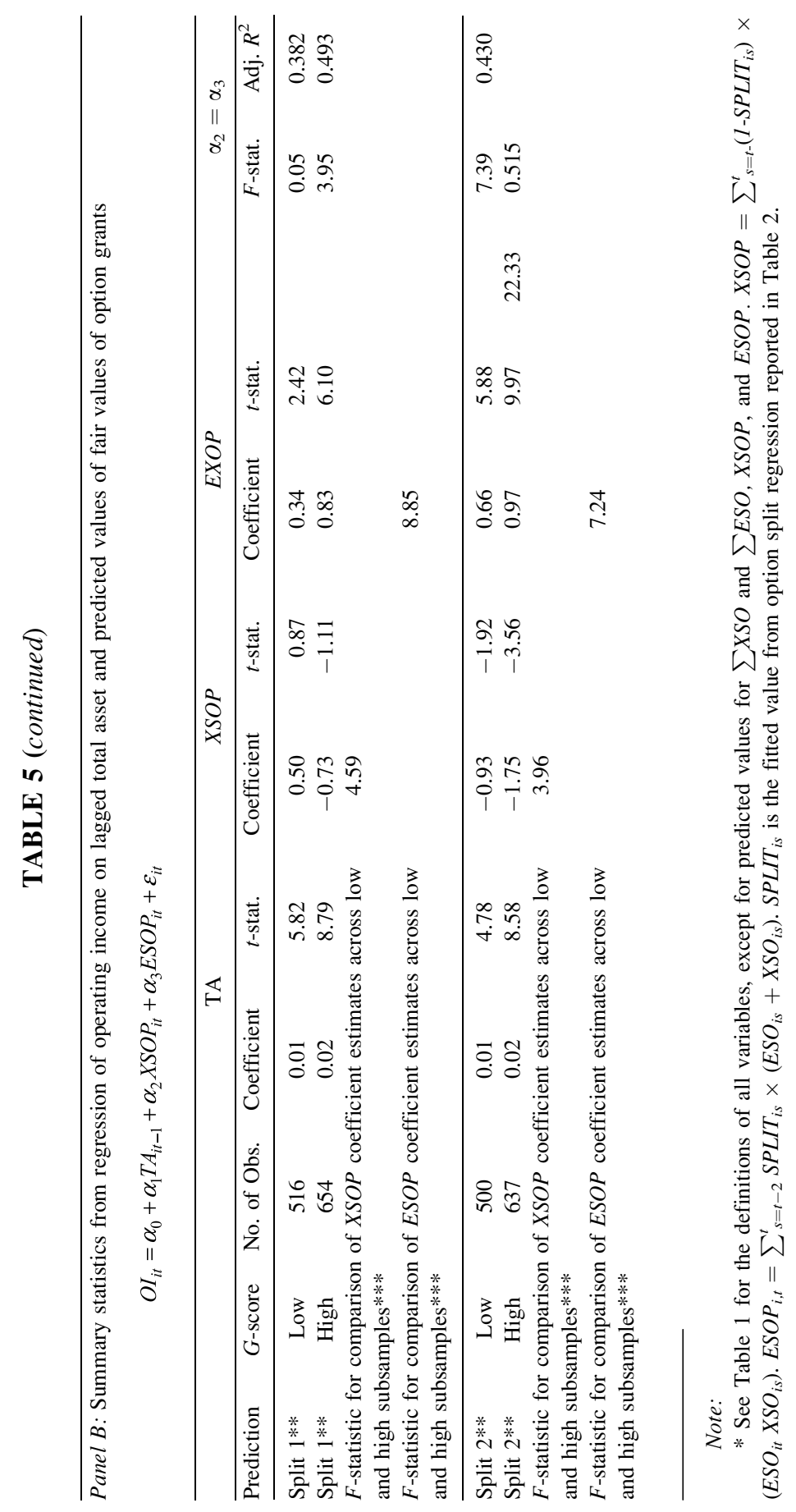




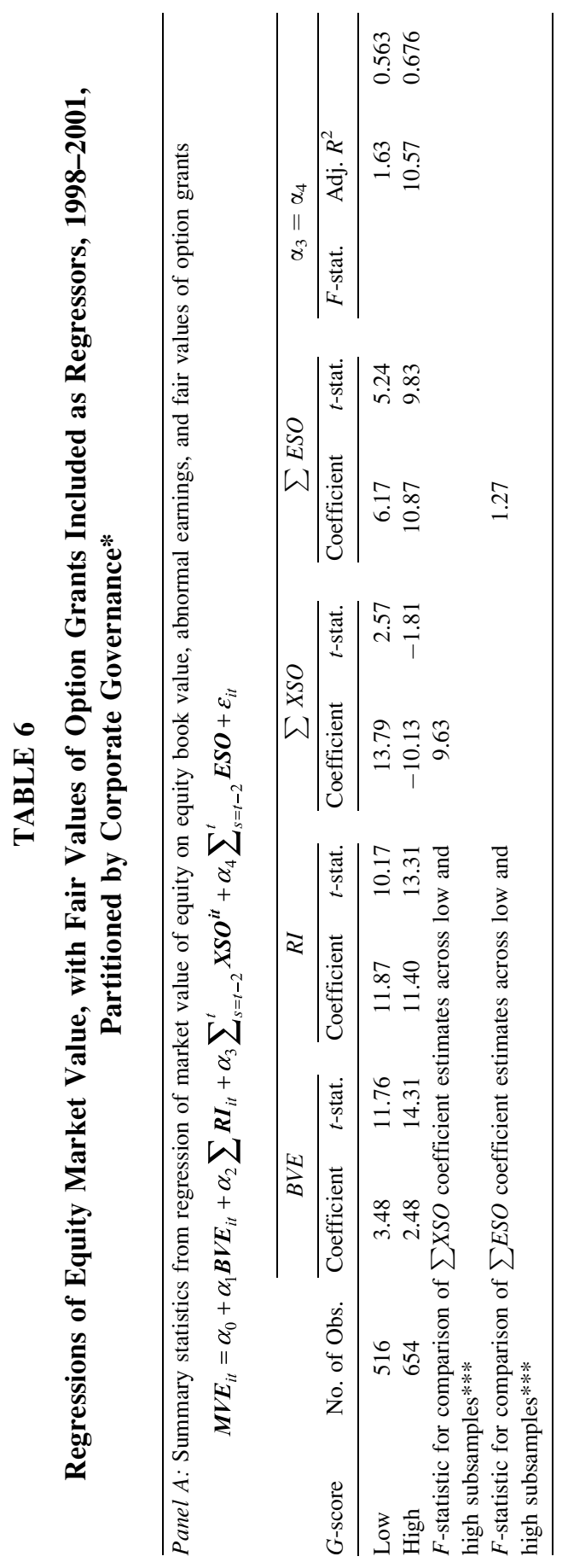




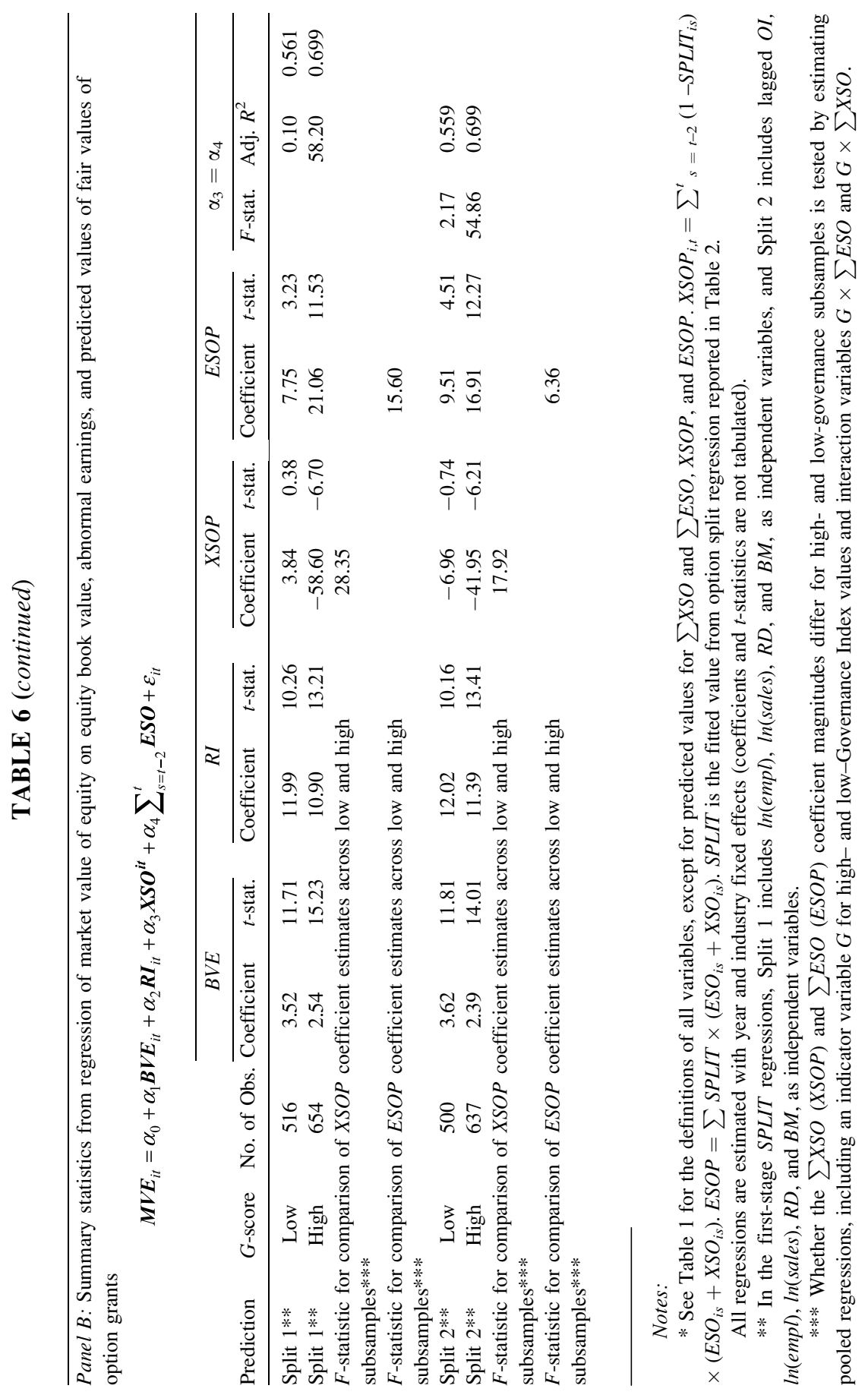


controls for endogeneity. However, the coefficient on executive options is insignificant for the good governance firms under both endogeneity specifications, and significantly negative for the poor governance firms ( $t$-statistics of -6.70 and -6.21 , respectively, without and with endogeneity controls for operating income). More important, the coefficient estimate on executive options is significantly lower for the poor governance firms than for the good governance firms ( $F$-statistics of 28.35 and 17.92). Furthermore, as with operating income, the effect of executive options on value is not significantly different for executive versus nonexecutive options when governance is good, but the effect of executive options is significantly below that for nonexecutive options when governance is relatively weak ( $F$-statistics of 58.20 and 54.86, respectively, for the specifications without and with controls for operating income). As with operating income, it appears that, for firms with poor governance, executive options create less value than nonexecutive options, and may actually destroy value.

\section{Robustness Tests}

The preceding sections suggest that a greater proportion of stock option grants tend to be awarded to executives when governance is relatively weak and that, in the face of weak governance, executive options tend to have a lower association with operating income and market value. Of course, establishing causality in this context is difficult because the empirical design issues are formidable. As a consequence, the preceding sections report results under a variety of specifications. In addition, we conducted a variety of supplemental analyses to assess robustness. First, as noted earlier, HRS regressions include squared terms to incorporate potential nonlinearity. We based our primary analysis on the linear specification for consistency with related studies, including BLMY (2002) and Aboody, Barth, and Kasznik (2004). We also replicated our analysis by including squared terms for $\sum X S O$ and $\sum E S O$. Results (not tabulated) indicate that conclusions are not affected by inclusion of squared terms. ${ }^{20}$

Second, as noted earlier, HRS first estimate coefficients for each lag of options and then sum the coefficients, while we first sum options across years and estimate a coefficient on the summed options. We chose our approach to be consistent with BLMY (2002). To ensure that our results are not driven by the decision to sum options first, we replicated our analysis by estimating separate coefficients for each lag and then summing. Conclusions are not sensitive to our decision to sum options across lags before estimating the regression.

20. Another specification issue is whether colinearity between $\sum X S O$ and $\sum E S O$ is sufficiently high to make coefficient estimates unstable. To assess the magnitude of colinearity, we computed variance inflation factors (VIFs) for our estimates. The VIFs were 4.67 and 5.33 for $\sum E S O$ and $\sum X S O$, respectively, which are well below the typical cutoff of 10 used to assess whether correlation is likely to be a concern. 
Third, the Governance Index represents a wide range of factors that may not all be equally important to governance. Although several studies use the aggregate governance scores as a measure of governance, it is possible that some components of governance are more relevant to the value of executive options. For example, the characteristics of the board are likely to be particularly relevant to the ability of executives to set compensation policy. Ideally, we would like to assess whether our findings are robust to alternative measures of the Governance Index that focus on board membership. However, we have access to a limited subset of the characteristics underpinning the Governance Index and, accordingly, focus on three: (1) whether the board terms are staggered, (2) whether there are fair price takeover provisions, and (3) whether there are limitations on actions by written consent. Untabulated findings from analyses based on a measure combining those three Governance Index components result in similar inferences to those based on the tabulated results.

Fourth, a potential concern is that our measures of executive options are computed based on the fair value of top five executive option grants as computed by $\mathrm{S} \& \mathrm{P}$ and reported by ExecuComp, while the value of the nonexecutive options is based on the fair value of option grants reported in the financial statement options footnote. An advantage of our approach is that option terms for executive plans often differ from those granted in broad-based plans, and the ExecuComp data explicitly take into account the terms of executive option grants. A disadvantage is that we cannot be certain that ExecuComp fair values for executive options are computed in a manner consistent with those for lowerlevel options (although both approaches typically apply a Black-Scholes valuation model). Although this potential inconsistency could add noise to our estimation procedures, it is not apparent that it would bias results. Nonetheless, to address the data inconsistency issue, we replicate our analysis by basing the split between executive and nonexecutive options on ExecuСотр estimates of the proportion of options granted to executive and nonexecutive employees. The measure of the option split computed using this approach is highly correlated with our approach (approximately 70\% Pearson correlation coefficient). However, data analysis indicated that there were sixteen outlier observations, where the two option split measures differ by more than 0.5 . Therefore, to mitigate the effect of these outliers, we conducted the replication two ways: (1) by replacing the extreme difference option split observations with our measure, and (2) by deleting these sixteen observations. ${ }^{21}$ Untabulated findings indicate that inferences are unaffected by using these alternative computations of option split.

Fifth, we replicated our analysis incorporating several determinants of broadbased option grants included in Core and Guay (2001). Because those variables reflect firm-level incentives to grant overall and apply to both executive and

21. Not surprisingly, the correlation between the option split amounts computed using the two approaches increased from about 70 percent to approximately 85 percent after deleting the extreme difference observations. 
nonexecutive options, it is not clear whether they would affect the focus of our paper, which is the split of options between executive and nonexecutive employees. Our results are robust to the inclusion of those controls.

Finally, a potential concern is that residual correlation could result in overstated levels of significance. To assess the potential effects of autocorrelation, we reestimated our analysis by year. Results are consistent for each year taken individually, although the effect of governance on the relation between options and operating income is not statistically significant in 2000 and 2001. An analysis clustering on year and firm yields results that are significant and consistent with those reported in our primary analysis.

\section{Summary and Conclusions}

We examine the determinants of the split between option grants to executive and nonexecutive employees and the relation between executive and nonexecutive options and firm performance and valuation. We first examine the split between executive and nonexecutive options and document that the depth to which options are granted in the organization is a function of governance in the organization. In particular, proportionally more options tend to be granted to executives when governance is weak. Our measure of governance here is based on the Governance Index of shareholder rights. The results suggest that the proportion of options granted to executives tends to be higher when managers are more insulated from shareholder pressure through mechanisms such as takeover defenses and other measures that make it more difficult for shareholders to monitor management.

We then evaluate the implications of executive and nonexecutive options for firm performance and valuation. Although both executive and nonexecutive options tend to be associated with better performance and higher market value, we find that the relation seems stronger for nonexecutive options than executive options. Although that seems surprising on its face, we argue that-if options are inefficiently granted to executives because of governance issues as argued in Bebchuk and Fried (2004) — executive options may do less to enhance firm value and, in the extreme, may reduce firm performance and value.

To investigate that possibility, we split the sample between good and poor governance based on the Gompers, Ishii, and Metrick (2003) measure. Our results suggest that, from performance and market value perspectives, executive options contribute less (and may even destroy value) in cases of poor governance.

Our results highlight the importance of differentiating between the type of options in research on firm performance and valuation and, further, differentiating between good and poor governance. Results are particularly interesting because governance appears to have relatively little effect on the performance and valuation implications of lower-level options, suggesting that governance matters to the efficacy of executive options but not to lower-level options. That difference is not surprising because lower-level employees have less control over the activities of the firm. 
Of course, our results are sensitive to caveats. Assessing causality in this type of setting is notoriously difficult because compensation design is, by its very nature, endogenous. We attempted to consider the endogeneity issue by evaluating determinants of the stock option split and by estimating our equations simultaneously.

\section{REFERENCES}

Aboody, D., M.E. Barth, and R. Kasznik. 2004. "SFAS 123 Stock-Based Compensation Expense and Equity Market Values." The Accounting Review 79: 251-276.

Ashbaugh, H., D. Collins, and R. LaFond. 2006. "The Effects of Corporate Governance on Firms' Credit Ratings." Journal of Accounting and Economics 42: 203-243.

Barth, M.E., W.H. Beaver, J.M. Hand, and W.R. Landsman. 1999. "Accruals, Cash Flows, and Equity Values.” Review of Accounting Studies 4: 205-229.

Barth, M.E., W.H. Beaver, J.M. Hand, and W.R. Landsman. 2005. “Accruals, Accounting-Based Valuation Models, and the Prediction of Equity Values." Journal of Accounting, Auditing, and Finance 20: 311-345.

Bebchuk, L., and A. Cohen. 2005. "The Cost of Entrenched Boards." Journal of Financial Economics 78: 409-433.

Bebchuk, L., and J. Fried. 2004. "Pay without Performance: The Unfulfilled Promise of Executive Compensation." Cambridge, MA: Harvard University Press.

Bell, T.B., W.R. Landsman, B.L. Miller, and S. Yeh. 2002. "The Valuation Implications of Employee Stock Option Accounting for Profitable Computer Software Firms." The Accounting Review 77: 971-996.

Bergstresser, D., M. Desai, and J. Rauh. 2006. "Earnings Manipulation, Pension Assumptions, and Managerial Investment Decisions." Quarterly Journal of Economics 121: 157-195.

Bergstresser, D., and T. Philippon. 2006. "CEO Incentives and Earnings Management." Journal of Financial Economics 80: 511-529.

Bowen, R., S. Rajgopal, and M. Venkatachalam. 2004. "Accounting Discretion, Corporate Governance, and Firm Performance." Working paper, University of Washington.

Brown, L.D., and M.L. Caylor. 2006. "Corporate Governance and Firm Valuation." Journal of Accounting and Public Policy 25: 409-434.

Callaghan, S.R., M. Stanford, and C. Subramaniam. 2006. "Do Broad-Based Option Compensation Plans Improve Future Firm Performance for Technology and Non-Technology Firms?" Working paper, Texas Christian University.

Carter, M. E., and L. J. Lynch. 2003. "The Consequences of the FASB's 1998 Proposal on Accounting for Stock Option Re-pricing." Journal of Accounting \& Economics 35: 51-72.

Collins, D.W., E.L. Maydew, and I.S. Weiss. 1997. "Changes in the Value-Relevance of Earnings and Equity Book Values over the Past Forty Years." Journal of Accounting and Economics 24: $39-67$.

Core, J., and W. Guay. 2001. "Stock Option Plans for Non-executive Employees." Journal of Financial Economics 61: 253-287.

Core, J., W. Guay, and T. Rusticus. 2006. "Does Weak Governance Cause Weak Stock Returns? An Examination of Firm Operating Performance and Investors' Expectations." Journal of Finance 61: 655-687.

Core, J., W. Guay, and R. Thomas. 2005. "Is U.S. CEO Compensation Inefficient Pay without Performance?" Michigan Law Review 103: 1142-1185.

Core, J., R. Holthausen, and D. Larcker. 1999. "Corporate Governance, Chief Executive Officer Compensation, and Firm Performance." Journal of Financial Economics 51: 371-406.

Dechow, P.M., A.P. Hutton, and R.G. Sloan. 1999. "An Empirical Assessment of the Residual Income Valuation Model." Journal of Accounting and Economics 26: 1-34.

Erickson, M., M. Hanlon, and E. Maydew. 2006. "Is There a Link between Executive Compensation and Accounting Fraud?" Journal of Accounting Research 44: 113-143.

Fama, E.F., and K.R. French. 1998. "Taxes, Financing Decisions, and Firm Value." Journal of Finance 53: 819-843. 
FASB (Financial Accounting Standards Board). 1995. Statement of Financial Accounting Standards No. 123: Accounting for Stock-Based Compensation. Norwalk, CT: FASB.

Gompers, P.A., J.L. Ishii, and A. Metrick. 2003. "Corporate Governance and Equity Prices." Quarterly Journal of Economics 118: 107-155.

Hall, B.J., and K. J. Murphy. 2002. "Stock Options for Undiversified Executives." Journal of Accounting \& Economics 33: 3-42.

Hall, B.J., and K. J. Murphy. 2003. "The Trouble with Stock Options." Journal of Economic Perspectives 17(3): 49-72.

Hanlon, M., S. Rajgopal, and T. Shevlin. 2003. "Are Executive Stock Options Associated with Future Earnings?" Journal of Accounting and Economics 36: 3-43.

Hausman, J. 1978. "Specification Tests in Econometrics." Econometrica 46: 1251-1271.

Hausman, J. 1983. "Specification and Estimation of Simultaneous Equations Models." In: Handbook of Econometrics. edited by Z. Griliches and M. Intriligator. Amsterdam: North-Holland.

Ittner, C., R. Lambert, and D. Larcker. 2003. "The Structure and Performance Consequences of Equity Grants to Employees of New Economy Firms." Journal of Accounting and Economics 34: 89-127.

Kmenta, J. 1971. Elements of Econometrics. New York: Macmillan Publishing Company.

Kothari, S.P., and J. Zimmerman. 1995. "Price and Return Models." Journal of Accounting and Economics 20: 155-192.

Larcker, D. 2003. "Discussion of "Are Executive Stock Options Associated with Future Earnings?", Journal of Accounting and Economics 36: 45-50.

Meulbroek, L.K. 2001. "The Efficiency of Equity-Linked Compensation: Understanding the Full Cost of Awarding Executive Stock Options.” Financial Management 30: 5-30.

Ohlson, J.A. 1995. "Earnings, Equity Book Values, and Dividends in Equity Valuation." Contemporary Accounting Research 11(2): 661-687.

Oyer, P. 2004. "Why Do Firms Use Incentives That Have No Incentive Effects." Journal of Finance 59: $1619-1650$

Oyer, P., and S. Schaefer. 2005. "Why Do Some Firms Give Stock Options to All Employees?: An Empirical Examination of Alternative Theories." Journal of Financial Economics 76: 99133.

Rajgopal, S., and T. Shevlin. 2002. "Empirical Evidence on the Relation between Stock Option Compensation and Risk Taking." Journal of Accounting and Economics 33:145-171. 
Copyright of Journal of Accounting, Auditing \& Finance is the property of Greenwood Publishing Group Inc. and its content may not be copied or emailed to multiple sites or posted to a listserv without the copyright holder's express written permission. However, users may print, download, or email articles for individual use. 